\title{
KEBIJAKAN UTANG PERUSAHAAN TAMBANG YANG TERDAFTAR DI BURSA EFEK INDONESIA
}

\author{
Pandu Adi Cakranegara ${ }^{1}$, Etty Susilowati ${ }^{2}$, Dian Sukma Deti ${ }^{3}$ \\ 1,3 Universitas Presiden, Kabupaten Bekasi, Indonesia \\ ${ }^{2}$ Universitas Budi Luhur, Jakarta, Indonesia \\ Email korespondensi: ${ }^{1}$ pandu.cakranegara@president.ac.id
}

\begin{abstract}
ABSTRAK
Penelitian ini bertujuan untuk mengetahui bagaimana perusahaan pertambangan mengelola kebijakan pendanaannya dengan menggunakan kebijakan utang jangka pendek dan jangka panjang. Penelitian ini merupakan penelitian kuantitatif dengan menggunakan metode regresi linier berganda. Dalam penelitian ini dibangun dua model yaitu model utang jangka pendek dan model utang jangka panjang. Metode pengambilan sampel yang digunakan adalah metode purposive sampling. Data yang digunakan adalah data panel, yaitu data berbagai variabel perusahaan dari tahun 2014 hingga 2019. Penelitian ini memberikan kontribusi pada ilmu keuangan terutama yang berkaitan dengan struktur modal yaitu pemilihan kebijakan utang. Model yang lebih mampu memberikan penjelasan tentang kemampuan berutang manajemen adalah model utang jangka pendek. Faktor profitabilitas dan likuiditas yang menjadi pendorong manajemen untuk melakukan utang jangka pendek. Ketika perusahaan memiliki profitabilitas dan likuiditas yang tinggi maka manajemen akan lebih yakin untuk mengambil utang jangka pendek. Sementara itu faktor yang mempengaruhi utang jangka panjang adalah kemampuan manajemen untuk membayar bunga utang.
\end{abstract}

Kata kunci: industri pertambangan; kebijakan utang; likuiditas; utang jangka panjang; utang jangka pendek

\begin{abstract}
This study aims to find out how mining companies manage their funding policies using short-term and long-term debt policies. This research is a quantitative research using multiple linear regression method. In this study, two models were built, namely the short-term debt model and the long-term debt model. The sampling method used is purposive sampling method. The data used is panel data, namely data on various company variables from 2014 to 2019. This research contributes to financial science, especially those related to capital structure, namely the selection of debt policies. The model that is more capable of providing an explanation of management's debt capability is the short-term debt model. Profitability and liquidity factors are the driving force for management to undertake short-term debt. When the company has high profitability and liquidity, management will be more confident to take on short-term debt. Meanwhile, the factor that affects long-term debt is the management's ability to pay interest on the debt.
\end{abstract}

\section{Keywords: debt policy; liquidity; long term debt; mining industries; short term debt}

\section{KETERANGAN ARTIKEL}

Riwayat Artikel: diterima: 1 Februari 2021; direvisi: 29 Maret 2021; disetujui: 1 Juni 2021

Klasifikasi JEL: H63

Cara mensitasi: Cakranegara, P., A., Susilowati, E., \& Deti, S., D. (2020). Kebijakan Utang Perusahaan Tambang yang Terdaftar di Bursa Efek Indonesia. JIAFE (Jurnal Ilmiah Akuntansi Fakultas Ekonomi), 7(1), 11-22. https://doi.org/10.34204/jiafe.v7i1.2933 
Pandu Adi Cakranegara: Kebijakan Utang Perusahaan ...

\section{PENDAHULUAN}

Ekuitas perusahaan tambang merupakan salah satu ekuitas yang memiliki performa yang terbaik dan merupakan safe haven untuk investor jangka panjang terutama di saat krisis (Baurens, 2010). Penilaian perusahaan tambang dengan menggunakan metode Discounted Cash Flow memiliki kelemahan yaitu perlu menentukan harga spot komoditas di masa depan (Schwartz, 1998). Pendekatan yang lebih sesuai adalah dengan menggunakan option price modelling. Ini berarti manajemen perusahaan akan memiliki beberapa skenario di masa depan yang mempengaruhi arus kas perusahaan.

Perusahaan tambang adalah perusahaan yang menjual barang komoditas dan dengan demikian perusahaan tambang adalah price taker (Baumol \& Blinder, 2016). Faktor-faktor yang mempengaruhi harga komoditas salah satunya adalah faktor makro ekonomi (Jena, 2015). Hal ini merupakan penegasan dari temuan Gillbert (1989) yang menyebutkan bahwa siklus bisnis dan nilai tukar US Dollar yang memberikan pengaruh signifikan terhadap harga komoditas. Di dalam konteks Indonesia perusahaan tambang memiliki beberapa pilihan dalam berutang antara lain pilihan menggunakan utang jangka pendek atau pilihan menggunakan utang jangka panjang. Penelitian-penelitian terdahulu meneliti faktor-faktor apa saja yang mempengaruhi tingkat utang perusahaan tambang. Penelitian ini membagi lebih jauh antara utang jangka pendek dan utang jangka panjang. Pembedaan ini dikarenakan utang jangka pendek dan utang jangka panjang mempunyai karakteristik yang berbeda sehingga faktor yang mempengaruhinya pun berbeda. Oleh karena itu penelitian ini berfokus pada faktor-faktor yang mempengaruhi utang jangka pendek dan faktor-faktor yang mempengaruhi utang jangka panjang.

Kesalahan dalam pengambilan keputusan pengambilan utang dapat menimbulkan permasalahan bagi manajemen. Hal ini salah satunya ditunjukkan oleh Goldstein (1998) yang menunjukkan bahwa utang jangka panjang dalam mata uang asing yang menyebabkan perusahaan-perusahaan properti di Indonesia jatuh pada 1998 dan selanjutnya menimbulkan krisis moneterdi Asia Tenggara. Mengingat hal itu maka manajemen perlu melihat keputusan utang yang seperti apa yang ideal bagi perusahaan, apakah utang jangka pendek atau utang jangka panjang. Untuk dapat mengetahui utang mana yang lebih ideal bagi perusahaan maka perusahaan juga harus melihat apakah faktor-faktor yang mendukung perusahaan untuk mengambil utang telah tersedia.

Allayannis (2003) meneliti bahwa walaupun hal ini berisiko namun risiko tersebut dapat dikurangi dengan hedging. Namun demikian, Agustia (2018) menemukan bahwa guncangan (shock) pada nilai US Dollar dan tingkat suku bunga akan memberikan guncangan (shock) pada harga komoditas. Sedangkan global bond yang diterbitkan oleh perusahaan tambang di Indonesia paling mungkin dalam mata uang US Dollar. Damodaran (2016) menyebutkan faktor yang paling berpengaruh dalam valuasi perusahaan atau faktor yang paling menimbulkan risiko bagi perusahaan tambang adalah faktor pendanaan. Dengan demikian penelitian ini berusaha meneliti faktor yang mempengaruhi pemilihan utang perusahaan. Pada kondisi apa perusahaan di Indonesia mengambil utang jangka panjang atau sebaliknya kondisi apa yang mendorong perusahaan untuk memilih pendanaan jangka pendek.

Kebijakan keuangan perusahaan baik kebijakan pendanaan maupun investasi ditujukan untuk memaksimalkan nilai perusahaan. Manajemen memaksimalkan nilai perusahaan dengan berinvestasi pada proyek yang membelikan arus kas paling tinggi dengan menggunakan cost of capital yang paling rendah. Cost of capital terdiri dari cost of debt dan cost of equity. Cost of debt berasal dari penggunaan utang sedangkan cost of equity berasal dari tingkat imbal balik yang diharapkan terhadap ekuitas perusahaan. Kebijakan utang yang salah satunya merupakan pemilihan jenis utang yaitu pemilihan utang jangka pendek dan jangka panjang akan mempengaruhi beban bunga yang ditanggung perusahaan. Ketika manajemen dapat memilih kombinasi tingkat bunga jangka pendek dan jangka panjang yang optimum maka manajemen akan meminimalkan beban utang yang selanjutnya akan meminimalkan cost of capital. Sebaliknya pengambilan kebijakan utang yang tidak optimum akan meningkatkan beban utang dan menimbulkan efek sebaliknya. 


\section{KAJIAN LITERATUR DAN PENGEMBANGAN HIPOTESIS Kebijakan Struktur Modal dan Kebijakan Utang}

Dalam mendanai operasional perusahaan bisa dari tiga alternatif sumber dana yaitu sumber dana internal, menerbitkan utang, dan menerbitkan ekuitas. Ide dari pecking orders theory adalah investor tidak mengetahui pasti nilai dari sebuah proyek dan risikonya. Dari sudut pandang investor makin menguntungkan suatu proyek maka manajemen akan berusaha mendanai dengan dana internal sementara semakin berisiko maka manajemen akan berusaha membagi risiko. Pada skenario penerbitan utang Custódio (2013) menyebutkan perusahaan menghadapi pilihan untuk menerbitkan utang dalam jangka pendek atau jangka panjang. Perusahaan dengan likuiditas yang lebih rendah akan memilih untuk memilih menerbitkan jangka panjang. Konsekuensinya adalah investor melihat bahwa perusahaan yang menerbitkan utang jangka panjang adalah perusahaan yang lebih berisiko.

Selain kebijakan Pecking Order Theory, metode lain yang digunakan manajer dalam mengambil kebijakan utang adalah teori Static Trade Off. Pada teori Static Trade Off manajer menghadapi trade off antara manfaat utang dan beban yang timbul dari penggunaan utang (Izakian dkk., 2016). Penggunaan utang menimbulkan keuntungan manfaat pajak yang diperoleh dari sifat beban bunga yang dapat dimasukkan menjadi biaya pengurang pajak. Manfaat ini sering disebut juga sebagai tax shield. Tanpa adanya manfaat ini maka tidak akan ada manfaat dalam penggunaan utang dalam struktur modal. Manfaat tax shield ini memiliki diminishing return, artinya pada saat perusahaan terlalu banyak berutang maka sisi ekuitas perusahaan akan menjadi lebih berisiko dan tingkat imbal balik ekuitas yang diharapkan menjadi tinggi sehingga penambahan utang tidak lagi memberikan manfaat seperti sebelumnya. Ketika perusahaan berutang di atas tingkat optimum maka akan timbul tekanan pada perusahaan. Tekanan ini berasal dari tingginya beban bunga yang akan mempengaruhi likuiditas perusahaan. Tekanan ini disebut juga sebagai financial distress.

Tingkat utang yang optimum adalah tingkat utang yang dapat memaksimalkan tax shield dan meminimalkan financial distress. Manfaat utang secara neto adalah selisih dari dua variabel ini. Ketika perusahaan mengoptimumkan kebijakan utang maka tax shield berada pada tingkat yang paling tinggi dan financial distress berada pada tingkat yang paling rendah (Altman dkk., 2019). Keunikan perusahaan tambang adalah tingkat volatilitasnya yang tinggi terutama di dalam operasional penambangan dan harga bahan tambang. Karena itu manajemen perlu memperhatikan kedua hal ini dalam mengambil utang. Ketika harga komoditas jatuh maka pendapatan perusahaan akan menurun sementara beban utang perusahaan tetap. Ini berarti perusahaan akan terkena risiko likuiditas dan jika hal ini terjadi terus menerus akan menyebabkan risiko solvency.

Karena pemilihan struktur modal mempengaruhi nilai perusahaan, maka studi ini menghubungkan antara bagaimana pemilihan utang pada perusahaan tambang dapat mempengaruhi nilai perusahaan tambang. Pemilihan utang jangka panjang dan jangka pendek memberikan pengaruh yang berbeda. Utang jangka panjang terkait dengan prospek jangka panjang perusahaan sedangkan utang jangka pendek terkait dengan prospek jangka pendek perusahaan. Utang jangka panjang di mata investor merupakan utang yang lebih berisiko dari utang jangka pendek. Oleh karena itu, dari sisi perusahaan maka utang jangka panjang adalah dana mahal bagi perusahaan. Dengan demikian, pemilihan kombinasi utang jangka pendek dan utang jangka panjang akan mempengaruhi total kos utang perusahaan dan selanjutnya akan mempengaruhi nilai perusahaan.

\section{Penelitian di Indonesia}

Di Indonesia Kristanti \& Isynuwardhana (2018) meneliti faktor-faktor yang mempengaruhi financial distress pada perusahaan terbuka dari berbagai industri yang terdaftar di Bursa Efek Indonesia. Penelitian Kristanti \& Isynuwardhana (2018) menemukan bahwa jumlah utang meningkatkan financial 
Pandu Adi Cakranegara: Kebijakan Utang Perusahaan ...

distress. Semakin besar jumlah utang semakin besar tingkat financial distress. Walaupun ini kelihatannya adalah sesuatu yang memiliki hubungan yang jelas namun perlu diingat bahwa jumlah utang perusahaan umumnya tidak terjadi dalam suatu waktu, melainkan akumulasi dari kebijakan utang perusahaan terutama kebijakan utang jangka panjang.

Widyarini (2014) selanjutnya meneliti faktor-faktor apa yang mempengaruhi tingkat utang atau leverage perusahaan tambang yang terdaftar di Bursa Efek Indonesia. Widyarini (2014) menemukan faktor-faktor seperti likuiditas, peluang pertumbuhan, agunan, pembayaran deviden, profitabilitas, dan ukuran perusahaan memiliki pengaruh terhadap tingkat utang perusahaan tambang di Indonesia. Ferdianto (2014) meneliti faktor-faktor yang mempengaruhi harga ekuitas perusahaan tambang di Bursa Efek Indonesia. Faktor profitabilitas yang diwakili oleh rasio return on asset memiliki pengaruh yang signifikan terhadap harga saham. Hal ini selaras dengan penelitian Widayarini (2014) di mana return on asset juga memiliki pengaruh signifikan terhadap tingkat utang. Dari kedua penelitian ini maka dapat disimpulkan ketika utang masih dapat menciptakan tax shield yang memberikan nilai atau meminimalkan cost of capital perusahaan maka nilai perusahaan akan naik (Nugent dkk., 2016).

Nilasari (2015) menemukan bahwa kepemilikan asing mendorong lebih banyaknya transparansi atau disclosure oleh perusahaan. Namun ketika investor asing berinvestasi pertama kali dan menghadapi informasi yang asimetris maka akan menjadi risiko untuk investor. Risiko ini meningkat ketika investor diminta dengan keterbatasan informasi tersebut untuk berinvestasi jangka panjang. Bagaimanapun juga keterbatasan informasi ini tidak dapat dianggap sebagai yang sepele. Vivianita \& Indudewi (2019) menyebutkan ada 42 kasus penipuan laporan keuangan perusahaan tambang di Indonesia. Pada penelitian Vivianita \& Indudewi (2019) indikator Return on Asset memiliki pengaruh signifikan terhadap financial statement fraud. Fraud yang terjadi adalah usaha perusahaan untuk terus mendapatkan dana dana segar atau utang dari investor dengan memalsukan profitabilitas. Augustia (2018) juga menemukan pengaruh tingkat utang perusahaan dengan manajemen laba. Makin tinggi tingkat utang perusahaan maka makin besar probabilitas perusahaan melakukan manajemen laba. Financial statement fraud sendiri dapat dipandang sebagai manajemen laba yang excessive.

Perbedaan penelitian ini dengan penelitian sebelumnya adalah pada penelitian ini struktur modal dalam struktur utang dibagi menjadi dua yaitu struktur utang jangka panjang dan struktur utang jangka pendek. Pembedaan ini dikarenakan kos berutang jangka panjang dan kos berutang jangka pendek berbeda. Untuk industri pertambangan yang memiliki nilai penjualan yang fluktuatif menyesuaikan harga pasar maka kos utang akan menjadi sesuatu yang penting. Ketika perusahaan memiliki lebih banyak kos utang jangka panjang di saat harga komoditas sedang turun maka nilai perusahaan akan turun. Sebaliknya ketika harga komoditas sedang tinggi maka akan lebih menguntungunkan bagi perusahaan untuk menggunakan utang jangka panjang. Berbeda dengan penelitian terdahulu penelitian ini membedakan keputusan utang jangka panjang dan jangka pendek. Kemudian penelitian ini meneliti faktor-faktor apa yang mempengaruhi kemampuan perusahaan untuk berutang jangka panjang dan jangka pendek.

\section{Pengembangan Hipotesis}

Pada penelitian ini terdapat sembilan hipotesis, yaitu.

$\mathrm{H}_{1}$ : terdapat pengaruh antara return on assets dengan short term debt

$\mathrm{H}_{2}$ : terdapat pengaruh antara interest coverage ratio dengan short term debt

$\mathrm{H}_{3}$ : terdapat pengaruh antara current assets ratio dengan short term debt

$\mathrm{H}_{4}$ : terdapat pengaruh antara log total assets dengan short term debt

$\mathrm{H}_{5}$ : terdapat pengaruh antara return on assets dengan long term debt

$\mathrm{H}_{6}$ : terdapat pengaruh antara interest coverage ratio dengan long term debt

$\mathrm{H}_{7}$ : terdapat pengaruh antara current assets ratio dengan long term debt 
$\mathrm{H}_{8}$ : terdapat pengaruh antara return on assets dengan long term debt

$\mathrm{H}_{9}$ : terdapat perbedaan antara $r$ square pada model short term debt dan long term debt

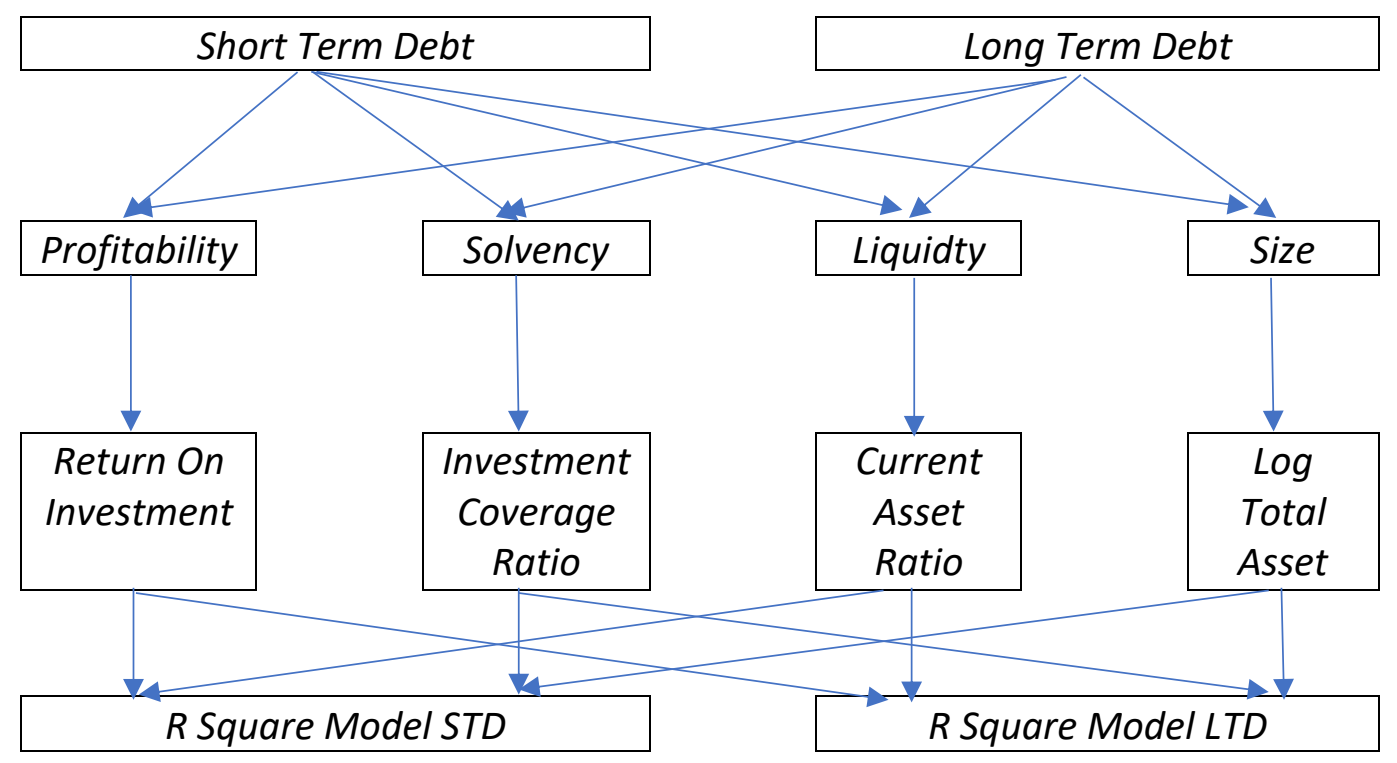

Gambar 1. Model Regresi Linear Berganda

\section{METODE PENELITIAN}

Penelitian ini merupakan penelitian kuantitatif para metrik dengan menggunakan statistik. Metode statistik yang digunakan adalah regresi linear berganda. Dalam penelitian ini terdapat dua model yang akan dibandingkan yaitu model pemilihan utang jangka pendek dan model pemilihan utang jangka panjang. Sementara itu variabel penjelasnya terdiri dari return on asset, interest coverage ratio, current asset ratio dan log total asset.

Data yang digunakan adalah data sekunder yaitu data dari laporan keuangan perusahaan tambang yang terdaftar di Bursa Efek Indonesia pada tahun 2014 hingga 2019. Sampel yang dipilih dengan menggunakan purposive sampling yaitu teknik pengambilan sampel dengan menetapkan kriteria terlebih dahulu terhadap sampel yang akan diambil (Etikan dkk., 2016). Kriteria pemilihan sampel terdiri dari tiga kriteria. Pertama adalah perusahaan yang menerbitkan laporan keuangan secara lengkap pada periode tahun 2014 hingga 2019. Kedua, perusahaan yang memiliki laporan keuangan dengan opini audit wajar tanpa pengecualian yang merupakan opini audit tertinggi. Ketiga, perusahaan yang memiliki data lengkap untuk variabel dalam penelitian.

\section{HASIL DAN PEMBAHASAN}

Dari kriteria sampel terpilih 16 perusahaan yang merupakan perusahaan publik di Bursa Efek Indonesia. Data yang didapat adalah data panel yaitu data tujuh variabel untuk kurun waktu tahun 2014 hingga 2019. Data dikumpulkan sesuai kriteria sampel yang telah ditentukan. Kemudian data melalui uji distribusi normal untuk mengetahui apakah data sudah terdistribusi normal dan untuk membuang data yang bersifat outlier dan mengganggu distribusi data. Setelah melalui uji distribusi normal maka di dapat data seperti pada Tabel 1. 
Pandu Adi Cakranegara: Kebijakan Utang Perusahaan ...

Tabel 1. Data Deskriptif

\begin{tabular}{|c|c|c|c|c|c|c|}
\hline & $\begin{array}{c}\text { ROA } \\
\mathrm{X} 1\end{array}$ & $\begin{array}{c}\text { Current } \\
\text { Asset Ratio } \\
\text { X2 }\end{array}$ & $\begin{array}{c}\text { Interest } \\
\text { Coverage } \\
\text { Ratio } \\
\text { X3 } \\
\end{array}$ & $\begin{array}{l}\log T A \\
\quad \times 4\end{array}$ & $\begin{array}{c}\text { STD/Equity } \\
\text { Y1 }\end{array}$ & $\begin{array}{c}\text { LTD/Equity } \\
\text { Y2 }\end{array}$ \\
\hline Mean & 0,036 & 1,895 & 13,527 & 6,636 & $-0,174$ & 0,537 \\
\hline Median & 0,040 & 1,565 & 5,755 & 6,760 & 0,085 & 0,240 \\
\hline Maximum & 1,220 & 9,220 & 161,820 & 8,010 & 6,180 & 7,700 \\
\hline Minimum & $-1,590$ & 0,180 & $-13,190$ & 4,760 & $-38,210$ & $-21,910$ \\
\hline Std. Dev. & 0,256 & 1,423 & 25,862 & 0,799 & 4,372 & 2,906 \\
\hline Observations & 80 & 80 & 80 & 80 & 80 & 80 \\
\hline
\end{tabular}

Dari hasil pengujian statistik deskriptif dapat dilihat bahwa dari enam belas perusahaan tambang yang menjadi sampel distribusinya datanya cenderung normal. Hal ini dapat dilihat dari angka median yang mendekati angka rata-rata. Sementara itu terdapat perusahaan tambang yang merugi yang terlihat dari ROA yang negatif dan juga kemampuan membayar utang (interest coverage) yang negatif. Namun demikian perusahaan tersebut masih menunjukkan kemampuan untuk bertahan secara operasional yang terlihat dari semua data aktiva lancar yang positif dan Total Aset yang positif.

Tabel 2 adalah hasil dari regresi linear berganda hasil pengolahan dengan menggunakan Utang Jangka Pendek sebagai variabel dependen.

Tabel 2. Model Utang Jangka Pendek

\begin{tabular}{lrrrr}
\hline \multirow{2}{*}{$\begin{array}{c}\text { Dependent Variable } \\
\text { Variable }\end{array}$} & \multicolumn{4}{c}{ Short-term Debt to Total Equity Ratio } \\
\cline { 2 - 5 } C & Coefficient & Std. Error & t-Statistic & \multicolumn{1}{c}{ Prob. } \\
\hline ROA & 0,783 & 2,851 & 0,275 & 0,784 \\
IC & 15,042 & 1,509 & 9,968 & $0,000^{* * *}$ \\
CA & 0,063 & 0,235 & 0,269 & 0,788 \\
Log TA & $-0,064$ & 0,015 & $-4,400$ & $0,000^{* * *}$ \\
R-squared & $-0,114$ & 0,430 & $-0,265$ & 0,791 \\
Adjusted R-squared & 0,591 & Mean dependent var & $-0,174$ \\
S.E. of regression & 0,570 & S.D. dependent var & 4,372 \\
Sum squared resid & 2,870 & Akaike info criterion & 5,007 \\
Log likelihood & 617,540 & Schwarz criterion & 5,155 \\
F-statistic & $-195,264$ & Hannan-Quinn criter & 5,066 \\
Prob(F-statistic) & 27,095 & Durbin-Watson stat & 1,867 \\
\hline$* * *$ highly significant pada tingkat di bawah 0,01 & &
\end{tabular}

Tabel 3 adalah hasil dari regresi linear berganda hasil pengolahan dengan menggunakan utang jangka pendek sebagai variabel dependen. 
Tabel 3. Model Utang Jangka Panjang

\begin{tabular}{lrrrr}
\hline \multirow{2}{*}{$\begin{array}{c}\text { Dependent Variable } \\
\text { Variable }\end{array}$} & \multicolumn{4}{c}{ Long-term Debt to Total Equity Ratio } \\
\cline { 2 - 5 } C & Coefficient & Std. Error & t-Statistic & \multicolumn{1}{c}{ Prob. } \\
\hline ROA & $-3,200$ & 2,119 & $-1,510$ & 0,145 \\
IC & $-1,385$ & 4,280 & $-0,323$ & 0,749 \\
CA & 1,410 & 0,559 & 2,522 & $0,019 * *$ \\
Log TA & $-0,005$ & 0,013 & $-0,371$ & 0,714 \\
& 0,314 & 0,327 & 0,962 & 0,346 \\
R-squared & & & & \\
Adjusted R-squared & 0,329 & Mean dependent var & 1,011 \\
S.E. of regression & 0,212 & S.D. dependent var & 1,659 \\
Sum squared resid & 1,473 & Akaike info criterion & 3,772 \\
Log likelihood & 49,887 & Schwarz criterion & 4,010 \\
F-statistic & $-47,816$ & Hannan-Quinn criter. & 3,845 \\
Prob(F-statistic) & 2,824 & Durbin-Watson stat & 0,195 \\
\hline
\end{tabular}

**significant pada tingkat di bawah 0,025

Dari pengolahan dengan menggunakan regresi linear berganda terpilih metode random effect. Persamaan regresi tersebut terlihat di bawah ini. Pada model Utang Jangka Pendek terdapat dua variabel yang signifikan pada tingkat $1 \%$ yaitu variabel independen Return On Asset dan Current Asset. Dari hasil regresi berganda terdapat dua model yang dihasilkan. Pertama adalah model pengambilan utang jangka pendek dan kedua adalah model pengambilan utang jangka panjang. Persamaan regresi dari masing-masing model terlihat di bawah ini.

$$
\begin{aligned}
& \mathrm{STD} / \mathrm{TE}=0.783+15.042 \mathrm{ROA}+0.063 \mathrm{IC}-0.064 \mathrm{CA}-0.114 \mathrm{Log} \mathrm{TA} \\
& \mathrm{LTD} / \mathrm{TE}=-3.200-1.386 \mathrm{ROA}+1.410 \mathrm{IC}-0.005 \mathrm{CA}+0.314 \mathrm{Log} \mathrm{TA}
\end{aligned}
$$

Berdasarkan hasil uji regresi linear berganda maka ada empat hipotesis yang diterima dan ada lima hipotesis yang diterima. Hipotesis yang diterima adalah sebagai berikut.

$\mathrm{H}_{1}$ : terdapat pengaruh antara return on assets dengan short term debt

$\mathrm{H}_{3}$ : terdapat pengaruh antara current assets ratio dengan short term debt

$\mathrm{H}_{6}$ : terdapat pengaruh antara interest coverage ratio dengan long term debt

$\mathrm{H}_{9}$ : terdapat pengaruh antara $r$ square pada model short term debt dan long term debt

Sementara itu lima hipotesis lainnya tidak mempunyai pengaruh signifikan baik terhadap Utang Jangka Pendek maupun Utang Jangka Panjang.

Dari hasil uji t terdapat dua variabel independen yang memiliki pengaruh positif terhadap variabel dependen. Variabel independen pertama yang memiliki pengaruh positif adalah return on asset. Ini artinya setiap kenaikan return on asset akan menaikkan kemampuan perusahaan untuk menambah utang jangka pendek. Artinya, semakin tinggi kemampuan perusahaan tambang menghasilkan laba atau semakin menguntungkan hasil dari tambang yang dikelola perusahaan maka investor akan semakin percaya untuk memberikan utang jangka pendek. 
Pandu Adi Cakranegara: Kebijakan Utang Perusahaan ...

Variabel independen kedua yang memiliki pengaruh signifikan positif adalah current asset ratio. Variabel current asset ratio mengukur seberapa banyak perusahaan mendanai aset jangka pendeknya dengan menggunakan utang jangka pendek. Semakin banyak aset jangka pendek yang didanai dengan utang jangka pendek maka akan semakin tinggi beban likuiditas perusahaan. Ini disebabkan utang jangka pendek menimbulkan beban utang yang harus dibayar dalam jangka pendek dengan menggunakan likuiditas perusahaan. Sebaliknya semakin rendah utang jangka pendek yang digunakan untuk mendanai aset jangka pendek maka akan semakin tinggi fleksibilitas likuiditas perusahaan. Dengan demikian perusahaan yang memiliki current asset ratio lebih tinggi memiliki fleksibilitas dan risiko yang lebih rendah pada saat terjadi fluktuasi pada pendapatan perusahaan. Dari sudut pandang investor maka perusahaan akan lebih tidak berisiko.

Dua hal ini konsisten dengan teori yang menyatakan bahwa investor jangka pendek akan memperhatikan likuiditas perusahaan yang dalam model di penelitian ini diwakili oleh variabel return on assets dan current asset ratio. Sementara itu pada model utang jangka panjang variabel yang signifikan adalah interest coverage ratio. Artinya, semakin tinggi penghasilan perusahaan maka semakin mudah perusahaan membayar bunga utang dan perusahaan semakin mampu menyisihkan sebagian pendapatan untuk dialokasikan guna membayar pokok utang. Hal ini konsisten dengan sudut pandang investor jangka panjang. Ini berbeda dengan investor jangka pendek yang fokus memperhatikan likuiditas. Likuiditas perusahaan berasal dari pendapatan perusahaan saat ini dan digunakan untuk membayar utang jangka pendek pada periode yang sama. Sedangkan investor jangka panjang memperhatikan tingkat kemampuan perusahaan membayar bunga utang. Jika semakin besar porsi pendapatan yang digunakan untuk membayar utang jangka pendek maka akan semakin sedikit sisa pendapatan yang disimpan perusahaan untuk membayar pokok pinjaman. Dengan demikian ketika perusahaan kesulitan membayar bunga jangka pendek atau likuiditas perusahaan turun maka kemungkinan perusahaan akan kesulitan membayar utang jangka panjangnya (Bardoscia dkk., 2019).

Angka $R$-Square menunjukkan kemampuan model untuk menjelaskan variabel dependen. Makin tinggi $R$-Square maka model tersebut makin cocok yang artinya model tersebut makin dapat menjelaskan variabel dependen. Dengan membandingkan nilai $R$-Square dari kedua model maka dapat dilihat model mana yang mampu menjelaskan variabel dependen lebih baik. Dari kedua model di atas. Model pengambilan utang jangka pendek memiliki $R$-Square yang lebih tinggi dari model pengambilan utang jangka pendek. Artinya variabel independen yang dipilih mampu menjelaskan faktor yang menyebabkan manajemen mengambil utang jangka pendek.

Perbandingan uji $R$ Square dilakukan tanpa menggunakan tes statistik untuk membandingkan dua rata-rata (Two Mean T Test). Melainkan dilakukan pembandingan langsung antara hasil $R$ Square dari kedua model. Hal ini dapat dilakukan pada penelitian ini karena hasil dari $R$ Square berada pada tingkat penjelas yang berbeda. $R$ Square pada model Utang Jangka Pendek berada di kisaran enam puluh persen ini artinya model dapat menjelaskan enam puluh persen variasi pada utang jangka pendek. Hal ini juga berarti bahwa model memiliki kemampuan untuk menjelaskan fenomena kebijakan utang jangka pendek perusahaan. Sebaliknya $R$ Square pada model utang jangka panjang berada di bawah lima puluh persen di kisaran tiga puluh persen. Ini berarti model yang ada hanya dapat menjelaskan tiga puluh persen variasi dari kebijakan utang jangka panjang perusahaan. Atau dengan kata lain model yang ada tidak dapat menjelaskan fenomena yang ada.

Dari kedua model keputusan utang jangka pendek dan utang jangka panjang ternyata model yang memiliki penjelasan lebih baik adalah model utang jangka pendek. Ini berarti penelitian ini menemukan faktor-faktor yang signifikan membuat perusahaan memilih pendanaan jangka pendek. Hasil temuan ini konsisten dengan teori bahwa ketika perusahaan memiliki profitabilitas yang positif dan likuiditas yang cukup maka perusahaan akan memiliki kemampuan untuk membayar kewajiban jangka pendeknya. 
Kedua faktor juga yang dalam penelitian ini menjadi faktor yang mempengaruhi pengambilan utang jangka pendek perusahaan.

Idealnya pendanaan aset jangka pendek didanai dengan menggunakan kewajiban jangka pendek. Apabila manajemen melakukan mismatch di mana aset jangka panjang didanai oleh kewajiban jangka pendek maka manajemen dapat mengalami kesulitan membayar utang sementara proyek belum memberikan imbal balik sepenuhnya. Temuan ini juga menunjukkan bahwa manajemen perusahaan tambang cenderung untuk disiplin dalam berutang. Hal ini terlihat dari pemilihan utang jangka pendek pada saat perusahaan memiliki profitabilitas dan likuiditas yang positif. Sebaliknya ketika manajemen yakin akan mampu menyisihkan arus kas baik untuk membayar bunga utang dan cicilan utang maka manajemen akan berutang jangka panjang.

Hasil uji regresi linear berganda terhadap model utang jangka pendek terdapat dua variabel independen yang signifikan yaitu return on assets dan current assets. Return on assets merupakan proxy dari profitability. Tingkat keuntungan memiliki pengaruh signifikan positif dengan pengambilan keputusan utang jangka pendek. Secara teori utang jangka pendek dibayar dengan menggunakan laba perusahaan sementara utang jangka panjang dibayar dengan menggunakan laba perusahaan yang disisihkan. Karena itu investor memerhatikan tingkat laba perusahaan yang akan digunakan untuk membayar utang jangka pendek. Semakin tinggi tingkat imbal balik yang ditunjukkan dengan semakin tingginya return on assets maka perusahaan akan mempunyai kemampuan membayar utang jangka pendek lebih tinggi.

Variabel independen kedua yang signifikan adalah current assets ratio yang merupakan indikator likuiditas. Ini menunjukkan bahwa pemberi utang jangka pendek memperhatikan likuiditas perusahaan dalam memberikan utang. Dari sisi manajemen ini berarti manajemen memperhatikan tingkat likuiditas jangka pendek yang ada dalam mengambil kebijakan utang jangka pendek. Hal ini sesuai dengan prinsip untuk memasangkan antara jenis kewajiban dan jenis aset, di mana aset jangka pendek seharusnya didanai dengan pendanaan jangka pendek sementara aset jangka panjang didanai dengan aset jangka panjang. Semakin tinggi current ratio menunjukkan bahwa semakin rendah porsi aset jangka pendek yang didanai dengan kewajiban jangka pendek. Konsekuensi dari ini adalah ketika terjadi fluktuasi pada pendapatan perusahaan maka perusahaan akan tetap dapat membayar kewajibannya karena porsi kewajiban jangka pendeknya lebih kecil dari aset jangka pendeknya.

Pada teori struktur modal, pemilihan struktur modal akan berpengaruh terhadap nilai perusahaan. Pada perusahaan tambang di mana harga penjualan barang tambang bergantung kepada permintaan dan penawaran maka pemilihan struktur utang akan mempengaruhi kos utang dan selanjutnya akan mempengaruhi nilai perusahaan. Penelitian ini menunjukkan bahwa perusahaan tambang cenderung memilih untuk menggunakan pendanaan jangka pendek. Sementara itu terdapat faktor-faktor yang secara spesifik mempengaruhi keputusan pendanaan. Keputusan pendanaan jangka pendek dipengaruhi oleh faktor profitabilitas dan likuiditas. Dengan adanya profitabilitas yang positif maka perusahaan akan memiliki arus kas yang positif. Selanjutnya arus kas yang positif akan memberikan likuiditas pada perusahaan sehingga perusahaan tidak takut untuk mengambil utang jangka pendek karena kelak utang jangka pendek akan dapat dibayar menggunakan hasil dari operasional perusahaan. Sementara itu faktor yang mempengaruhi keputusan perusahaan tambang untuk berutang jangka panjang adalah kemampuan membayar bunga utang. Asalkan perusahaan memiliki kemampuan untuk membayar bunga maka perusahaan berani untuk berutang jangka panjang.

Hasil penelitian ini konsisten dengan penelitian dari Custódio (2013) di Amerika Serikat di mana walaupun perusahaan lebih menyukai utang jangka panjang tetapi investor menyukai perusahaan yang memiliki likuiditas yang cukup untuk memenuhi kewajibannya sehingga mendorong perusahaan untuk memilih pendanaan jangka pendek. 
Pandu Adi Cakranegara: Kebijakan Utang Perusahaan ...

Ukuran yang digunakan sebagai variabel kontrol dalam penelitian ini tidak memiliki pengaruh yang signifikan. Hal ini berbeda dengan penelitian Tim dkk. (2011) di Malaysia di mana perusahaan tambang yang berukuran besar lebih memilih untuk berutang secara jangka panjang. Keunggulan pendanaan ini berdasarkan penelitian ini tidak dimiliki oleh perusahaan tambang di Indonesia. Hal yang selaras dengan penelitian Tim dkk. (2011) adalah investor Indonesia juga melihat profitabilitas dan likuiditas sebagai faktor dalam memberikan pinjaman.

Pilihan manajemen untuk menggunakan utang jangka pendek sebagai alternatif pendanaan selaras dengan temuan dari Custodio dkk. (2013) di Amerika Serikat, di mana tren perusahaan Amerika Serikat untuk cenderung memilih utang jangka panjang. Custodio dkk. (2013) mengemukakan bahwa tren ini didorong oleh informasi yang asimetris antara manajemen dengan investor. Ini juga didorong oleh karakteristik perusahaan tambang yang kompleks (Baurens, 2010). Menurut Baurens (2010) investor yang memiliki akses untuk memperoleh informasi maka akan mengambil keputusan dengan informasi yang lebih sedikit dibandingkan manajemen yang mempunyai akses dan teknologi untuk memperoleh informasi tersebut. Konsekuensinya investor mengandalkan asumsi dan memberi suatu premi risiko untuk memberikan kompensasi atas informasi yang asimetris.

Dalam penelitian ini yang juga selaras dengan Thim \& Nee. (2011) interest coverage ratio bukan merupakan suatu hal signifikan. Ini berarti yang dilihat oleh investor sebenarnya bukan kemampuan membayar bunga utang melainkan likuiditas perusahaan secara keseluruhan. Selanjutnya, jika investor menganggap penting bagi perusahaan untuk menjaga interest coverage ratio pada tingkat tertentu maka investor akan memasukkan hal ini ke dalam perjanjian utang piutang. Penelitian dari Vivianita \& Indudewi. (2019) yang menyebutkan terdapat 42 kasus financial statement fraud perusahaan tambang di Indonesia juga bisa menjadi salah satu faktor yang mendorong untuk investor lebih berhati-hati dan cenderung untuk memilih memberikan utang jangka pendek.

Bila hasil ini dikaitkan dengan implikasinya untuk manajemen, maka pihak manajemen perlu memperhatikan terutama indikator profitabilitas dan likuiditas dalam mengambil keputusan utang jangka pendek. Konsekuensi dari kurangnya likuiditas dan menurunnya profitabilitas akan menyebabkan tingkat kepercayaan pemberi utang dan investor menurun sehingga timbul yang disebut dengan financial distress. Penghematan tingkat bunga (tax shield) yang diperoleh dari penggunaan utang dapat hilang karena adanya pemborosan atau naiknya tingkat bunga akibat financial distress. Trade off dari dua hal ini yaitu dari tax shield dan cost of financial distress akan berdampak pada cost of capital yang lebih tinggi. Selanjutnya dengan meningkatnya cost of capital perusahaan maka valuasi perusahaan akan turun.

Pada perusahaan tambang utang jangka panjang digunakan untuk memulai suatu proses penambangan yaitu proses eksplorasi hingga membangun infrastruktur tambang. Selanjutnya untuk operasional penambangan sehari-hari setelah bahan tambang ditemukan dan siap diekstraksi tidak semahal di awal. Pada saat ini perusahaan tambang akan menggunakan utang jangka pendek untuk mendanai operasional. Proses penambangan di awal merupakan proses yang berisiko dan mahal. Tidak mudah untuk menemukan titik yang tepat untuk menentukan lokasi bahan tambang. Risiko kedua adalah proses eksplorasi yang memakan waktu. Waktu yang dibutuhkan dalam eksplorasi dapat singkat ataupun panjang bergantung pada kondisi tambang yang unik di masing-masing tempat. Karena itu perlu digunakan utang jangka panjang melihat tingginya ketidak pastian yang ada terutama dalam hal waktu.

Risiko ketiga datang dari sisi non operasional perusahaan tambang yaitu pada harga komoditas di jangka panjang. Harga komoditas di masa depan untuk komoditas tambang bersifat volatile. Volatilitas ini dipengaruhi oleh berbagai hal seperti permintaan dan penawaran serta tren yang ada seperti tren penggunaan energi terbarukan yang dapat menekan permintaan komoditas pertambangan dan selanjutnya menurunkan harga jual komoditas. 
Risiko keempat terutama adalah risiko pada perusahaan tambang yang beroperasi di negara berkembang. Indonesia memiliki risiko yang tinggi yang terkait dengan risiko kebijakan dan ketidakpastian hukum dan kondisi sosial ekonomi. Salah satunya adalah penambangan di daerah yang di mana tanah adalah tanah adat seperti Papua, Kalimantan dan Sumatera. Hal ini dapat menimbulkan risiko dengan masyarakat sekitar. Sementara itu kebijakan yang berubah seiring dengan bergantinya pemerintahan akan membawa risiko pada perusahaan pertambangan terutama terkait perpanjangan konsesi pertambangan.

Perusahaan tambang terutama perusahaan tambang yang terdaftar di Bursa Efek Indonesia dapat memaksimalkan nilai saham dengan mengambil keputusan pendanaan yang tepat. Dengan berutang perusahaan tambang tidak hanya dapat mencukupi kebutuhan dananya tetapi juga menciptakan tax shield. Di sisi lain tingkat utang yang terlalu tinggi akan menciptakan financial distress yang justru akan menghilang keuntungan dari tax shield. Keputusan pendanaan yang sesuai yaitu dengan menggunakan utang jangka pendek untuk mendanai aset jangka pendek dan menggunakan utang jangka panjang untuk mendanai aset jangka panjang akan meminimalkan cost of capital perusahaan dan dengan demikian memaksimalkan nilai sahan perusahaan.

\section{KESIMPULAN}

Ada beberapa hal terkait perusahaan tambang yang dapat disimpulkan dari penelitian ini. Pertama, penggunaan global bond merupakan hal yang berisiko bagi perusahaan karena investor cenderung memilih untuk berinvestasi pada jangka pendek. Hal ini terlihat dari model pada penelitian ini di mana model utang jangka pendek mampu menjelaskan tingkat utang jangka pendek perusahaan tambang. Kedua, indikator profitabilitas dan likuiditas menjadi perhatian utama investor dalam berinvestasi. Karena sifat dari perusahaan tambang yang penuh ketidakpastian terutama dalam jangka panjang baik dalam operasional pertambangan, harga komoditas di masa depan, maupun ketidakpastian politik mempengaruhi risiko yang ditanggung investor dan selanjutnya tingkat imbal balik yang diharapkan. Ketiga, investor tidak melihat ukuran perusahaan sebagai suatu keunggulan atau menganggap perusahaan besar mempunyai kemampuan membayar utang lebih baik. Kembali ke kesimpulan kedua investor tetap melihat indikator performa profitabilitas dan likuiditas

\section{DAFTAR PUSTAKA}

Agustia, Y. P., \& Suryani, E. (2018). Pengaruh Ukuran Perusahaan, Umur Perusahaan, Leverage, Dan Profitabilitas Terhadap Manajemen Laba (Studi Pada Perusahaan Pertambangan yang Terdaftar di Bursa Efek Indonesia Periode 2014-2016). Jurnal Aset (Akuntansi Riset), 10(1), 71-82.

Allayannis, G., Brown, G. W., \& Klapper, L. F. (2003). Capital Structure And Financial Risk: Evidence From Foreign Debt Use In East Asia. The Journal of Finance, 58(6), 2667-2710.

Altman, E. I., Hotchkiss, E., \& Wang, W. (2019). Corporate Financial Distress, Restructuring, And Bankruptcy: Analyze Leveraged Finance, Distressed Debt, And Bankruptcy. John Wiley \& Sons.

Bardoscia, M., Barucca, P., Codd, A. B., \& Hill, J. (2019). Forward-Looking Solvency Contagion. Journal of Economic Dynamics and Control, 108, 103755.

Baumol, W. J., \& Blinder, A. S. (2015). Microeconomics: Principles And Policy. Nelson Education.

Baurens, S. (2010). Valuation Of Metals And Mining Companies. Basinvest.

Jena, P., K. (2015). Commodity Prices and Macroeconomic Variables in India: An Auto-Regressive Distributed Lag (ARDL) Approach. Munich Personal RePEc Archive.

Custódio, C., Ferreira, M. A., \& Laureano, L. (2013). Why Are US Firms Using More Short-Term Debt?. Journal of Financial Economics, 108(1), 182-212.

Damodaran, A. (2016). Security Analysis For Investment And Corporate Finance. John Wiley \& Sons. 
Etikan, I., Musa, S. A., \& Alkassim, R. S. (2016). Comparison Of Convenience Sampling And Purposive Sampling. American Journal Of Theoretical And Applied Statistics, 5(1), 1-4.

Ferdianto, E. (2014). Analisis Pengaruh Return On Asset (ROA), Debt To Equity Ratio (DER), Net Profit Margin (NPM) Dan Current Ratio (CR) Terhadap Harga Saham: Studi Empiris Pada Perusahaan Tambang Yang Terdaftar Di Bursa Efek Indonesia Tahun 2011-2013. Uinjkt Repository.

Goldstein, M. (1998). The Asian Financial Crisis: Causes, Cures, And Systemic Implications. Peterson Institute Press.

Klossek, P., \& Klossek, A. (2014). The Specific Value Of Junior Mining Companies: Are Common Valuation Methods Appropriate?. Journal of Business Valuation and Economic Loss Analysis, 9(1), 105-144.

Nugent, T., \& Leidner, J. L. (2016, December). Risk Mining: Company-Risk Identification From Unstructured Sources (Paper Presentation). IEEE 16th International Conference on Data Mining Workshops (ICDMW).

Nilasari, E. (2015). Pengaruh Profitabilitas, Kepemilikan Institusional, Kepemilikan Asing dan Size Terhadap CSR Disclosure Perusahaan Tambang (Mining Sector) Yang Melakukan Listing di Bursa Efek Indonesia Tahun 2010-2012. UDiNus Repository, 1-20.

Kristanti, F., T., \& Isynuwardhana, D. (2018). Prediction of Financial Distress of Industrial Sectors in Indonesian Companies Using Survival Analysis. Jurnal Keuangan dan Perbankan, 22(1): 23-36

Schwartz E. (1998). Valuing Long-Term Commodity Assets. Financial Management, 27, 57-66.

Thim, C. K., Choong, Y. V., \& Nee, C. S. (2011). Factors affecting financial distress: The case of Malaysian public listed firms. Corporate Ownership and Control, 8(4), 345-351.

Vivianita, A., \& Indudewi, D. (2019). Financial Statement Fraud Pada Perusahaan Pertambangan Yang Dipengaruhi Oleh Fraud Pentagon Theory (Studi Kasus Di Perusahaan Tambang Yang Terdaftar Di Bei Tahun 2014-2016). Jurnal Dinamika Sosial Budaya, 20(1), 1-15.

Widyarini, R. (2014). Analisis Faktor-Faktor yang Mempengaruhi Leverage Pada Perusahaan Tambang yang Terdaftar Di Bursa Efek Indonesia pada Periode Tahun 2009-2012. Diponegoro Journal of Accounting, 0,757-765. 